\title{
Irrational Use of Antibiotics among University Students
}

\author{
Elagib, H. M. ${ }^{1}$, Al-Tamimi, R. KH. ${ }^{2}$, Alolaiqi, G. F. ${ }^{3}$, Algharbi, N. A. ${ }^{4}$, Alsamaan, B. A. ${ }^{5}$, Alsharedah, D. N. ${ }^{6}$, \\ Almohaimel, N. M. ${ }^{7}$ \\ ${ }^{1}$ Faculty of Medicine, Department of Pharmacology, University of Hail / Saudi Arabia \\ 2, 3, 4,5, 6, 7 Faculty of Medicine, 4th year students, University of Hail / Saudi Arabia
}

\begin{abstract}
Intrduction: Irrational prescribing has a number of adverse consequences for the patient as well as the community. The important ones are delay, inability in affording relief or cure of disease. More adverse drug effects are prolongation of hospitalization; loss of mandays, increased morbidity and mortality. Moreoveremergence of microbial resistance, financial loss to the patient, community, loss of patient's confidence in the doctor, lowering of health standards of patients, community and perpetuation of public health problem.Antimicrobial resistance is a rapidly increasing world wide problem.Irrational use of antibiotics is the major determinant in the development of resistance. Material and Method: This study was done by questionnaire comprising 15 questions were used. The questions asked for determining the level ofknowledge were true or false and yes or no questions.students (excluding those from the Faculty of Medicine) of age University, We studied 361(Saudi Arabian) students male and female of The sampling group was divided into five groups including five faculties these are: Engineering, Sciences, Education, Pharmacy, Physiotherapy The observations for each question are tabulated. Statistical comparison was done using SPSS (Anova test) was used P values less than 0.05 were considered significant. Results: The aim of antibiotic use for common cold was $46.16 \%)(P<0.05)$ and, to decrease fever was $(53.64 \%)(P<0.05)$ in all Groups. In all groups the respondents started antibiotics by themselves when they were ill $33.24 \%(P<0.05)$ although $(61.77 \%)$ $(P<0.05)$ of all groups agree that antibiotics should be started with doctors' prescription. During their last infection of the respondents used the same antibiotic as previously prescribed by their doctors $(50.42 \%)(P<0.05)$. Conclusions: In the present study results showed that self-medication and the irrational use of antibiotics were common among university student in Hail. The rational use of ntibiotics may be favored by improving knowledge about these drugs. Such an idea should be made clear to the public, where many diseases would become very difficult to treat with the currently known antibiotics. National education programs about the danger of irrational antibiotic use and restriction of antibiotic without prescription.
\end{abstract}

Keywords: Irrational, Antibiotic, Students, University

\section{Introduction}

\subsection{Antibiotics}

Antibiotics are substances that kill or inhibit the growth of microorganisms. They are either produced naturally, by living cells, or synthetically, as analogs of natural substances. The first knowledge of antibiotics was provided by Fleming in 1928, when he discovered that a product of the penicillium mold had the power to destroy many diseaseproducing microorganisms (1).

Each antibiotic has its own characteristic 'spectrum' of activity against various microorganisms. A broad-spectrum antibiotic is effective against many microorganisms; a narrow-spectrum antibiotic is effective against only a few microorganisms (1).

Antimicrobial resistance is a rapidly increasing world wide problem.Irrational use of antibiotics is the major determinant in the development of resistance. Many factors such as economics, politics, doctors' knowledge and experience, diagnostic uncertainty, and pharmaceutical marketing lead to irrational use of antibiotics. Numerous studies of adults have shown that patients' expectations orphysicians' perceptions of those expectations affect the physicians' prescribing behavior $(2,3)$.
Drug resistance refers to tolerance of microorganisms to inhibitory action of antimicrobials.e.g. Staphylococci to penicillin (4)

\subsection{Objectives of the Study}

- To evaluate the knowledge, attitude and behavior of antibiotic uses in the student groups of a University in a country where the antibiotics are taken without prescriptions.

- The students represent the most important effective members in the society to be aware about most important adverse effects of irrational prescribing for the patient as well as the community and to decrease antibiotic resistance.

- To determine self medication with antibiotics in this population group.

\section{Materials and Methods}

\subsection{Material}

This study was planned as a cross sectional study on studets of Age University except those from faculty of Medicine, was done by questionnaire which was developed by the supervisors and students. A questionnaire comprising 15 questions were used. The questions asked for determining the level ofknowledge were true or false questions. Questions to determine the attitude and behaviour wereprepared as yes/no and multiple choice questions.In true 


\section{International Journal of Science and Research (IJSR) \\ ISSN (Online): 2319-7064 \\ Index Copernicus Value (2013): 6.14 | Impact Factor (2015): 6.391}

and false and yes/no questions differences between the 5 groups are tested. In multiple choice questions differences between the answers are tested.

\subsection{Study Participants}

We studied 361(Saudi Arabian) students male and female of different ages and different colleges.

The sampling group was divided into five groups, $\operatorname{group}(\mathrm{A})$ from faculty of engineering, group (B) from faculty of science, group (C) from faculty of education, group (D) from the faculty of pharmacy group (E) from faculty of physiotherapy.

\subsection{Data Collections}

The interviewer explained to participants the objective of the study and asked standards questions. The study participants were interviewed separately in the colleges (Engineering college (55), Science College (51), Pharmacy College (64), Physiotherapy College (91) and Education College (100).
The observations for each question are tabulated. Statistical comparison was done using SPSS (Anova test) was used to compare the answers given by the 5 groups and $\mathrm{P}$ values less than 0.05 were considered significant.

\section{Result}

3.1. Comparison between numbers of students from different faculties:

The sample of 361 students was taken from the University of Hail, including five faculties these are: Engineering, Sciences, Education, Pharmacy, Physiotherapy and their percentage contribution were $(14.1 \%)$, ( $27.7 \%)(17.7 \%)$, $(25.2 \%),(15.2 \%)$ respectively (as shown in table $1 \&$ figure $1)$.

Table 1: Names of faculties and number of students

\begin{tabular}{|l|l|l|}
\hline Faculty name & Frequency & Percentage \\
\hline Engineering & 55 & 15.2 \\
\hline Sciences & 51 & 14.1 \\
\hline Education & 100 & 27.7 \\
\hline Pharmacy & 64 & 17.7 \\
\hline Physiotherapy & 91 & 25.2 \\
\hline Total & 361 & 100.0 \\
\hline
\end{tabular}

College

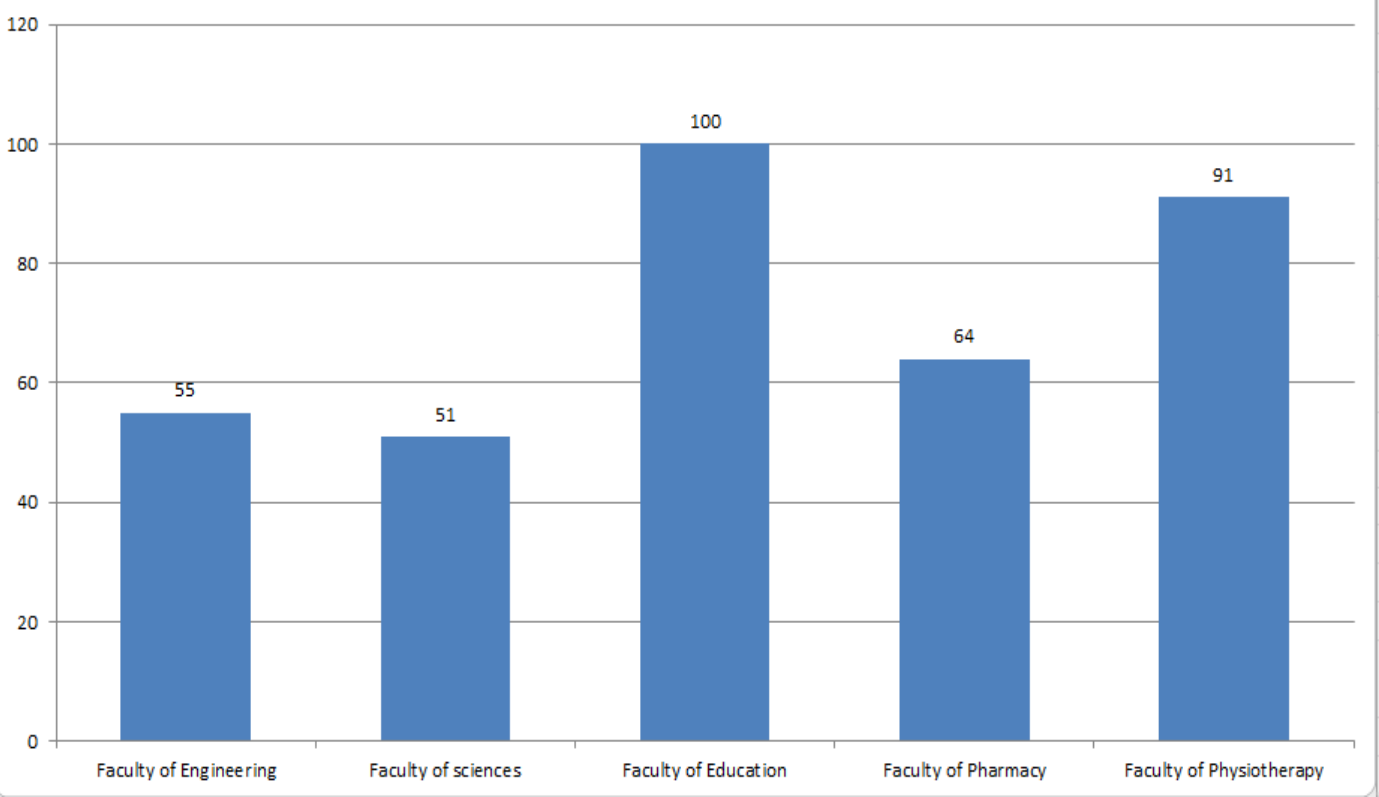

Figure 1: Names of faculties and number of students

3.2. Comparison between males and females upon the gender

In this study the percentage of students contributing was $(25.2 \%)$ of males and $(74.8 \%)$ female as shown (in table 2 figure 2).

Table 2: Comparison between males and females upon the gender

\begin{tabular}{|c|c|c|}
\hline Gender & Frequency & Percentage \\
\hline Male & 91 & 25.2 \\
\hline Female & 270 & 74.8 \\
\hline Total & 361 & 100.0 \\
\hline
\end{tabular}




\section{International Journal of Science and Research (IJSR) \\ ISSN (Online): 2319-7064}

Index Copernicus Value (2013): 6.14 | Impact Factor (2015): 6.391

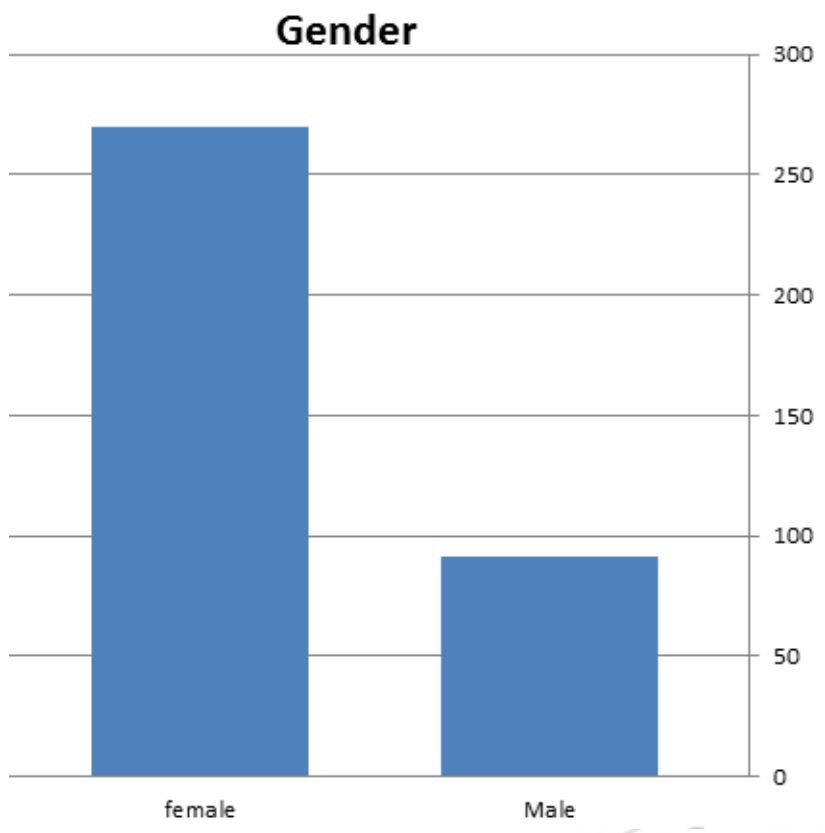

Figure 2: Comparison between males and females upon the gender

3.3. Comparison between males and females upon the age In this study the percentage of students contributing was $(25.2 \%)$ of males and $(74.8 \%)$ female as shown (in table 3 figure 3 ).
Table 3: Comparison between males and females upon the

\begin{tabular}{|c|c|c|}
\hline Age in years & Frequency & Percentage \\
\hline $18-20$ & 31 & 8.6 \\
\hline $21-23$ & 296 & 82.0 \\
\hline $24-28$ & 34 & 9.4 \\
\hline Total & 361 & 100.0 \\
\hline
\end{tabular}

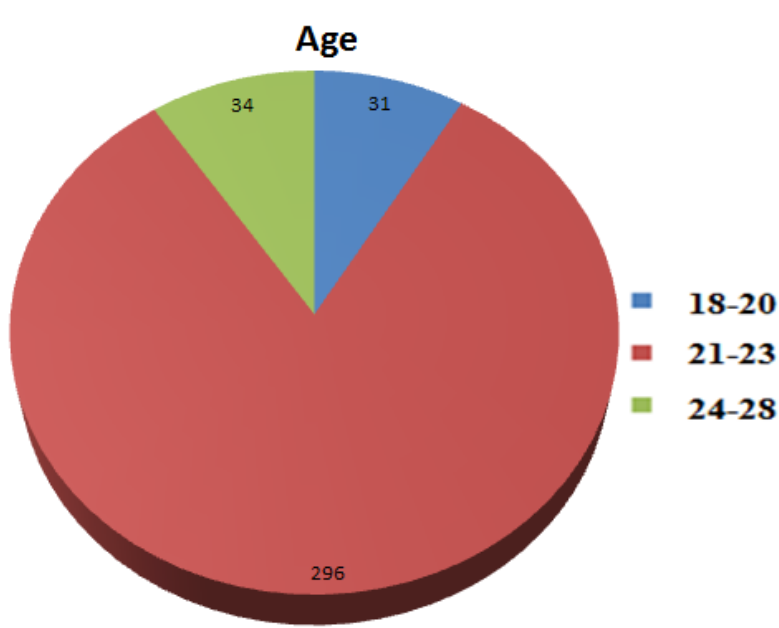

Figure 3: Comparison between males and females upon the age

\subsection{Analysis of the questionnaires question}

The questionnaire and the answers given to the questions about knowledge, attitude and behavior by the groups are summarized in tables 4and 5.

Table 4: The knowledge of the groups on the antibiotics use

\begin{tabular}{|c|c|c|c|c|c|c|c|c|c|c|c|c|c|c|c|c|c|c|c|}
\hline & \multicolumn{3}{|c|}{ Group (A) } & \multicolumn{3}{|c|}{ Group(B) } & \multicolumn{3}{|c|}{ Group(C) } & \multicolumn{3}{|c|}{ Group (D) } & \multicolumn{3}{|c|}{ Group (E) } & \multicolumn{3}{|c|}{ Total } & \multirow[t]{2}{*}{$\mathbf{P}$} \\
\hline & $\mathbf{T}$ & $\mathbf{F}$ & 96 & $\mathbf{T}$ & $\mathbf{F}$ & 96 & $\mathbf{T}$ & $\mathbf{F}$ & 96 & $\mathbf{T}$ & $\mathbf{F}$ & 96 & $\mathbf{T}$ & $\mathbf{F}$ & 96 & $\mathbf{T}$ & $\mathbf{F}$ & 96 & \\
\hline $\begin{array}{l}\text { 1- The purpose of the wse of } \\
\text { antibiotic } \\
\text { A) To reduce heat (T/F) }\end{array}$ & 39 & 16 & 86.67 & 21 & 30 & 41.18 & 50 & 50 & 50.00 & 29 & 35 & 45.31 & 54 & 37 & 59.34 & $\begin{array}{c}19 \\
3\end{array}$ & $\begin{array}{c}16 \\
8\end{array}$ & 53.46 & $\mathbf{B}$ \\
\hline $\begin{array}{l}\text { B) To overcome the pain } \\
\text { (T/F) }\end{array}$ & 39 & 16 & 86.67 & 24 & 27 & 47.06 & 59 & 41 & 59.00 & 32 & 32 & 50.00 & 55 & 36 & 60.44 & $\begin{array}{c}20 \\
9\end{array}$ & $\begin{array}{r}15 \\
2 \\
\end{array}$ & 57.89 & A \\
\hline $\begin{array}{l}\text { C) To overcome the } \\
\text { weakness and fatigue (T/F) }\end{array}$ & 26 & 29 & 57.78 & 10 & 41 & 19.61 & 32 & 68 & 32.00 & 14 & $\mathbf{5 0}$ & 21.88 & $\overline{32}$ & 59 & 35.16 & $\begin{array}{c}11 \\
4\end{array}$ & $\begin{array}{r}24 \\
7\end{array}$ & 31.58 & $\bar{B}$ \\
\hline D) For the common cold (T/F) & 29 & 26 & 64.44 & 22 & 20 & 43.14 & 50 & 50 & 50.00 & 39 & 25 & 6094 & 27 & 64 & 29.67 & $\begin{array}{c}16 \\
7\end{array}$ & $\begin{array}{c}19 \\
4\end{array}$ & 46.26 & B \\
\hline $\begin{array}{l}\text { 2- How to start the use of the } \\
\text { antibiotic : } \\
\text { A) Antibiotic found in the } \\
\text { house for lack of loss of } \\
\text { time (T/F) }\end{array}$ & 17 & 38 & 37.78 & 12 & 39 & 23.53 & 32 & 68 & 32.00 & 13 & 51 & 20.31 & 29 & 62 & 31.87 & $\begin{array}{c}10 \\
3\end{array}$ & $\begin{array}{c}25 \\
8\end{array}$ & 28.53 & A \\
\hline $\begin{array}{l}\text { B) Medical prescription } \\
(\mathbf{T} / \mathbf{F})\end{array}$ & 44 & 11 & 97.78 & 41 & 10 & 80.39 & 82 & 18 & 82.00 & 60 & 4 & 93.75 & 60 & 31 & 6593 & $\begin{array}{c}28 \\
7\end{array}$ & 74 & 79.50 & B \\
\hline $\begin{array}{l}\text { C) The advice of a } \\
\text { pharmacist (T/F) }\end{array}$ & 23 & 32 & 51.11 & 13 & 38 & 25.49 & 36 & 64 & 36.00 & 19 & 45 & 29.69 & 27 & 64 & 29.67 & $\begin{array}{c}11 \\
8\end{array}$ & $\begin{array}{c}24 \\
3 \\
\end{array}$ & 32.69 & A \\
\hline $\begin{array}{l}\text { 3-How long is wse of the } \\
\text { antibiotic: } \\
\text { A) Until the end of the } \\
\text { medication tray (T/F) }\end{array}$ & 11 & 44 & 24.44 & 3 & 48 & 5.88 & 8 & 92 & 8.00 & 2 & 62 & 3.13 & 20 & 71 & 21.98 & 44 & $\begin{array}{c}31 \\
7\end{array}$ & 12.19 & B \\
\hline $\begin{array}{l}\text { B) Until the symptoms } \\
\text { disappear (T/F) }\end{array}$ & 24 & 31 & 53.33 & 17 & 34 & 33.33 & 40 & 60 & 40.00 & 17 & 47 & 26.56 & 39 & 52 & 42.86 & $\begin{array}{c}13 \\
7 \\
\end{array}$ & $\begin{array}{c}22 \\
4\end{array}$ & 37.95 & $\bar{A}$ \\
\hline $\begin{array}{l}\text { C) According to the } \\
\text { doctor's advice on } \\
\text { T/F) }\end{array}$ & 38 & 17 & 84.44 & 40 & 11 & 78.43 & 76 & 24 & 76.00 & 53 & 11 & 82.81 & 61 & 30 & 67.03 & $\begin{array}{c}26 \\
8\end{array}$ & 93 & 74.24 & $\bar{A}$ \\
\hline $\begin{array}{l}\text { 4- How is the use of the } \\
\text { antibiotic, which is taken twice } \\
\text { a day : } \\
\text { A) When you wake up } \\
\text { in the morning (T/F) }\end{array}$ & 25 & 30 & 55.56 & 18 & $\mathbf{3 3}$ & 35.29 & 37 & 63 & 37.00 & 25 & 39 & 39.06 & 40 & 51 & 4396 & $\begin{array}{c}14 \\
5\end{array}$ & $\begin{array}{c}21 \\
6\end{array}$ & 40.17 & A \\
\hline $\begin{array}{l}\text { B) Before going to sleep } \\
\text { in the evening (T/F) }\end{array}$ & 31 & 24 & 68.89 & 29 & 22 & 56.86 & 52 & 48 & 52.00 & 38 & 26 & 59.38 & 54 & 37 & 59.34 & $\begin{array}{c}20 \\
4\end{array}$ & $\begin{array}{c}15 \\
7 \\
\end{array}$ & 56.51 & A \\
\hline $\begin{array}{l}\text { 5- Non-use of an appropriate } \\
\text { antibiotic } \\
\text { A) Do you think that } \\
\text { the use of } \\
\text { inappropriate } \\
\text { antibiotic had any } \\
\text { dangerous (T/F) }\end{array}$ & 41 & 8 & 98.44 & 44 & 7 & 86.27 & 90 & 10 & 90.00 & 59 & 5 & 92.19 & 73 & 18 & 80.22 & $\mathbf{3 1}$ & 48 & 86.70 & A \\
\hline
\end{tabular}

T/F true/False and percentages denote those who said "True" : A : P $>0.05$ not significant, $B$ : $P<0.05$ significant 


\section{International Journal of Science and Research (IJSR) \\ ISSN (Online): 2319-7064 \\ Index Copernicus Value (2013): 6.14 | Impact Factor (2015): 6.391}

3.4.1. The purpose of the use of antibiotic:

The result obainedt for the prupose of the use of antibiotic to reduce heat for all groups $(53.45 \%)(\mathrm{P}<0.05)$ in group $\mathrm{A}$ $(86.67 \%)$, in group B $(41.15 \%)$, in group C $(50 \%)$, in group D $(45.3 \%)$ and in group E $(59.34 \%)$ gathered on the same opinion.

To overcome the pain for all groups $(57.89 \%)(\mathrm{P}>0.05)$ in group A $(86.67 \%)$, in group B $(47.05 \%)$, in group C (59\%), in group D (50\%) and in group $\mathrm{E}(60.44 \%)$.

To overcome weakness and fatigue for all groups $(31.56 \%)(\mathrm{P}<0.05)$ in group A $(57.78 \%)$ in group B $(19.6 \%)$, in group $\mathrm{C}(32 \%)$, in group $\mathrm{D}(21.88 \%)$ and in group $\mathrm{E}(35.16 \%)$

For common cold $(46.26 \%)(\mathrm{P}<0.05)$ in group A $(64.44 .78 \%)$ in group B $(43.14 \%)$, in group C $(50 \%)$, in group D $(60.94 \%)$ and in group $\mathrm{E}(29.67 \%)$.

This means that there was irrational use for antibiotic use to reduce heat, overcome weakness, fatigue and for common cold.

\subsubsection{How to start the use of antibiotics:}

The result obainedt for how to start the use of the antibiotic found in the house for lack of loss of time for all groups $(28.53 \%)(\mathrm{P}>0.05)$, in group $\mathrm{A}(37.78 \%)$ in group $\mathrm{B}$ $(23.53 \%)$, in group C $(32 \%)$, in group D $(20.31 \%)$ and in group $\mathrm{E}(31.87 \%)$.

By medical prescription $(79.50 \%)(\mathrm{P}<0.05)$, in group $\mathrm{A}$ $(97.78 \%)$ in group B $(80.39 \%)$, in group C $(82 \%)$, in group $\mathrm{D}(93.75 \%)$ and in group $\mathrm{E}(56.93 \%)$.

For advise of pharmacist $(32.69 \%)(\mathrm{P}<0.05)$ in group A $(51.11 \%)$ in group B $(25.49 \%)$, in group C $(36 \%)$, in group $\mathrm{D}(29.69 \%)$ and in group $\mathrm{E}(29.69 \%)$.

\subsubsection{How long is use of the antibiotic?}

The result of obtained for the duration of the use of antibiotic until the end of medication trey $(12.19 \%)(\mathrm{P}<0.05)$, in group A $(24.44 \%)$ in group B $(5.88 \%)$, in group C $(8 \%)$, in group D $(3.13 \%)$ and in group $\mathrm{E}(21.93 \%)$.

For until the symptoms disappear (37.95\%) ( $\mathrm{P}>0.05)$, in group A $(53.33 \%)$ in group B $(33.33 \%)$, in group C $(40 \%)$, in group $\mathrm{D}(26.56 \%)$ and in group $\mathrm{E}(42.56 \%)$.

Acccording doctor's advice $(74.24 \%)(\mathrm{P}>0.05)$, in group A $(84.44 \%)$ in group B $(78.43 \%)$, in group C $(76 \%)$, in group $\mathrm{D}(82.81 \%)$ and in group $\mathrm{E}(67.03 \%)$.

\subsubsection{How is the use of antibiotic, which is taken twice a} day?

The result of obtained for how to use the antibiotic, which was taken twice a day when you wake up in the morning $(40.17 \%)(\mathrm{P}>0.05)$, in group A $(55.56 \%)$ in group $\mathrm{B}$ $(35.29 \%)$, in group C $(37 \%)$, in group D $(39.06 \%)$ and in group $\mathrm{E}(43.96 \%)$.

For before going to sleep in the evening $(56.51 \%)(\mathrm{P}>0.05)$, in group A $(65.59 \%)$ in group B $(56.86 \%)$, in group C $(52 \%)$, in group D $(59.35 \%)$ and in group $\mathrm{E}(59.34 \%)$.

3.4.5. Do you think that the use of appropriate antibiotic had any dangerous?

The result of obtained for the inappropriate use of antibiotic had any dangerous $(86.70 \%)(\mathrm{P}>0.05)$, in the group $\mathrm{A}$ $(98.44 \%)$, in group B $(86.27 \%)$, in group C $(90.00 \%)$, in group D $(92.19 \%)$, and in group E $(80.22 \%)$.

The result of obtained for the use of the antibiotic until the patient was not that the antibiotic had any dangerous $(30.75 \%)$ ( $\mathrm{P}>0.05)$, in group A $(98.44 \%)$, in group $\mathrm{B}$ $(86.27 \%)$, in group C $(90.00 \%)$, in group D $(92.19 \%)$ and in group $\mathrm{E}$ gathered on the same opinion.

Table 5: The attitude and behavior of the groups about the antib

\begin{tabular}{|c|c|c|c|c|c|c|c|c|c|c|c|c|c|c|c|c|c|c|c|}
\hline $\begin{array}{l}\text { C) Until the symptoms } \\
\text { disappear }(\mathrm{Y} / \mathrm{N})\end{array}$ & 25 & 30 & 55.56 & 27 & 24 & 52.94 & 42 & 58 & 42.00 & 21 & 43 & 32.81 & 55 & 36 & 60.44 & 170 & 191 & 47.09 & B \\
\hline $\begin{array}{l}\text { 12- Do you have an antibiotic in } \\
\text { your home pharmacy }(\mathrm{Y} / \mathrm{N})\end{array}$ & 36 & 19 & 80.00 & 33 & 18 & 64.71 & 68 & 32 & 68.00 & 33 & 31 & 51.56 & 63 & 28 & 69.23 & 233 & 128 & 64.54 & $\mathrm{~A}$ \\
\hline $\begin{array}{l}\text { 13- Is the high temperature have } \\
\text { any "fever" a strong motivation } \\
\text { for the use of the antibiotic } \mathrm{Y} / \mathrm{N} \text { ) }\end{array}$ & 41 & 14 & 91.11 & 28 & 23 & 54.90 & 64 & 36 & 64.00 & 30 & 34 & 46.88 & 56 & 35 & 61.54 & 219 & 142 & 60.66 & B \\
\hline $\begin{array}{l}\text { 14- Do you expect that it is } \\
\text { necessary to take antibiotics if } \\
\text { the disease is caused by a virus } \\
\text { such as cold (Y/N) }\end{array}$ & 36 & 19 & 80.00 & 23 & 28 & 45.10 & 52 & 48 & 52.00 & 38 & 26 & 59.38 & 53 & 38 & 58.24 & 202 & 159 & 55.96 & $\mathrm{~A}$ \\
\hline $\begin{array}{l}\text { 15. Have you ever heard of } \\
\text { before all the bacteria resistance } \\
\text { to antibiotics }(\mathrm{Y} / \mathrm{N})\end{array}$ & 25 & 30 & 55.56 & 28 & 23 & 54.90 & 53 & 47 & 53.00 & 46 & 18 & 71.88 & 37 & 54 & 40.66 & 189 & 172 & 52.35 & B \\
\hline
\end{tabular}


International Journal of Science and Research (IJSR)

ISSN (Online): 2319-7064

Index Copernicus Value (2013): 6.14 | Impact Factor (2015): 6.391

\begin{tabular}{|c|c|c|c|c|c|c|c|c|c|c|c|c|c|c|c|c|c|c|c|}
\hline & \multicolumn{3}{|c|}{ Group (A) } & \multicolumn{3}{|c|}{ Group(B) } & \multicolumn{3}{|c|}{ Group(C) } & \multicolumn{3}{|c|}{ Group (D) } & \multicolumn{3}{|c|}{ Group (E) } & \multicolumn{3}{|c|}{ Total } & \multirow[t]{2}{*}{$\mathrm{P}$} \\
\hline & $\mathbf{Y}$ & $\mathbf{N}$ & $\%$ & $\mathbf{Y}$ & $\mathbf{N}$ & $\%$ & $\mathbf{Y}$ & $\mathbf{N}$ & $\%$ & $\mathbf{Y}$ & $\mathbf{N}$ & $\%$ & $\mathbf{Y}$ & $\mathbf{N}$ & $\%$ & $\mathbf{Y}$ & $\mathbf{N}$ & $\%$ & \\
\hline $\begin{array}{l}\text { 6-Do you use an antibiotic in } \\
\text { order not to be sick (Y/N) }\end{array}$ & 17 & 38 & 37.78 & 14 & 37 & 27.45 & 29 & 71 & 29.00 & 16 & 48 & 25.00 & 35 & 56 & 38.46 & 111 & 250 & 30.75 & $\mathrm{~A}$ \\
\hline $\begin{array}{l}\text { 7-Do you begin antibiotic } \\
\text { yourself when you're sick (Y/N) }\end{array}$ & 17 & 38 & 37.78 & 18 & 33 & 35.29 & 30 & 70 & 30.00 & 14 & 50 & 21.88 & 41 & 50 & 45.05 & 120 & 241 & 33.24 & $\mathrm{~B}$ \\
\hline $\begin{array}{l}\text { 8-Do you use an antibiotic } \\
\text { prescribed by your doctor when } \\
\text { it is irregular }(\mathrm{Y} / \mathrm{N})\end{array}$ & 9 & 46 & 20.00 & 9 & 42 & 17.65 & 14 & 86 & 14.00 & 8 & 56 & 12.50 & 21 & 70 & 23.08 & 61 & 300 & 16.90 & $\mathrm{~A}$ \\
\hline $\begin{array}{l}\text { 9- What do you do when you } \\
\text { think the antibiotic ineffective : } \\
\text { A) Stops take it and go } \\
\text { to the doctor (Y/N) }\end{array}$ & 35 & 20 & 77.78 & 28 & 23 & 54.90 & 62 & 38 & 62.00 & 47 & 17 & 73.44 & 37 & 54 & 40.66 & 209 & 152 & 57.89 & $\mathrm{~B}$ \\
\hline $\begin{array}{l}\text { B) Stops take it and go } \\
\text { to another doctor } \\
(\mathrm{Y} / \mathrm{N})\end{array}$ & 25 & 30 & 55.56 & 15 & 36 & 29.41 & 29 & 71 & 29.00 & 15 & 49 & 23.44 & 45 & 46 & 49.45 & 129 & 232 & 35.73 & $\mathrm{~B}$ \\
\hline $\begin{array}{l}\text { C) I take it specified } \\
\text { period }(\mathrm{Y} / \mathrm{N})\end{array}$ & 17 & 38 & 37.78 & 20 & 31 & 39.22 & 41 & 59 & 41.00 & 31 & 33 & 48.44 & 20 & 71 & 21.98 & 129 & 232 & 35.73 & $\mathrm{~B}$ \\
\hline $\begin{array}{l}\text { 10- How did you get the } \\
\text { antibiotic in the last infection : } \\
\text { A) Use antibiotic and } \\
\text { former friend, who } \\
\text { advised me to do } \\
\text { (V/N) }\end{array}$ & 14 & 41 & 31.11 & 8 & 43 & 15.69 & 20 & 80 & 20.00 & 8 & 56 & 12.50 & 20 & 71 & 21.98 & 70 & 291 & 19.39 & $\mathrm{~A}$ \\
\hline $\begin{array}{l}\text { B) The antibiotic used } \\
\text { as the previous recipe } \\
\text { my doctor }(\mathrm{Y} / \mathrm{N})\end{array}$ & 31 & 24 & 68.89 & 22 & 29 & 43.14 & 57 & 43 & 57.00 & 42 & 22 & 65.63 & 30 & 61 & 32.97 & 182 & 179 & 50.42 & B \\
\hline $\begin{array}{l}\text { C) I went to the doctor } \\
\text { and used by consulted } \\
(\mathrm{Y} / \mathrm{N})\end{array}$ & 33 & 22 & 73.33 & 30 & 21 & 58.82 & 61 & 39 & 61.00 & 41 & 23 & 64.06 & 45 & 46 & 49.45 & 210 & 151 & 58.17 & $\mathrm{~A}$ \\
\hline $\begin{array}{l}\text { D) I asked the } \\
\text { pharmacist and used } \\
\text { by consulted }(\mathrm{Y} / \mathrm{N})\end{array}$ & 24 & 31 & 53.33 & 17 & 34 & 33.33 & 34 & 66 & 34.00 & 11 & 53 & 17.19 & 45 & 46 & 49.45 & 131 & 230 & 36.29 & B \\
\hline $\begin{array}{l}\text { 11- How do you use an antibiotic } \\
\text { when you last enemy : } \\
\text { A) Until ends the course } \\
\text { (V/N) }\end{array}$ & 12 & 43 & 26.67 & 7 & 44 & 13.73 & 15 & 85 & 15.00 & 4 & 60 & 6.25 & 19 & 72 & 20.88 & 57 & 304 & 15.79 & $\mathrm{~A}$ \\
\hline $\begin{array}{l}\text { B) According to the } \\
\text { doctor's advice on } \\
(\mathrm{Y} / \mathrm{N})\end{array}$ & 35 & 20 & 77.78 & 31 & 20 & 60.78 & 66 & 34 & 66.00 & 49 & 15 & 76.56 & 42 & 49 & 46.15 & 223 & 138 & 61.77 & B \\
\hline
\end{tabular}

Y/N Yes/No and percentages denote those who said "Yes" A: $\mathrm{P}>0.05$ not significant. B: $\mathrm{P}<0.05$ significant.

3.4.6. Do you use an antibiotic in order not to be sick?

The result of obtained for the use of antibiotic so as not to be patient $(30.75 \%)(\mathrm{P}>0.05)$, in group $\mathrm{A}(37.78 \%)$, in group $\mathrm{B}$ $(27.45 \%)$, in group C $(29 \%)$, in group D $(25 \%)$ and in group E (38.46\%).

\subsubsection{Do you begin antibiotic by your self when you are} sick:

The result of obtained for begin antibiotic by yourself when you are sick $(33.24 \%)(\mathrm{P}<0.05)$, in group $\mathrm{A}(37.78 \%)$, in group B $(35.29 \%)$, in group C $(30 \%)$, in group D $(21.88 \%)$ and also in group E (45.05\%).3.4.8. Do you use an antibiotic prescribed by your doctor when it is irregular: The result of obtained for the use an antibiotic prescribed by your doctor when it is irregular $(16.90 \%)(\mathrm{P}>0.05)$, in group A $(20 \%)$, in group B $(17.65 \%)$, in group C $(14 \%)$, in group D $(12.50 \%)$ and in group E $(23.08 \%)$

3.4.9. What do you do when you think the antibiotic ineffective?

The result of obtained for what to do when you think the antibiotic you're using is not effective was to stop taking and go to the doctor $(57.89 \%)$ ( $\mathrm{P}<0.05)$, in group A $(77.78 \%)$, in group B $(54.90 \%)$, in group $\mathrm{C}(62 \%)$, in group $\mathrm{D}(73.44 \%)$ and in group $\mathrm{E}(40.66 \%)$ gathered on the same opinion.
For stop take it and go to another doctor $(35.37 \%)(\mathrm{P}<0.05)$, in group A $(55.56 \%)$, in group B $(29.41 \%)$, in group $\mathrm{C}(29 \%)$, in group D $(23.44 \%)$ and in group E (29.45\%) gathered on the same opinion.

I take it sepecfied period $(35.73 \%)(\mathrm{P}<0.05)$, in group $\mathrm{A}$ $(37.78 \%)$, in group B $(39.22 \%)$, in group $\mathrm{C}(41 \%)$, in group $\mathrm{D}(48.44 \%)$ and in group E $(21.98 \%)$.

3.4.10. How did you get the antibiotic in the last infection: The result of obtained for the use antibiotic and former friend, who advised me to do for all groups $(19.39 \%)(\mathrm{P}>$ $0.05)$, in group A $(31.11 \%)$, in group B $(15.69 \%)$, in group $\mathrm{C}(20 \%)$, in group D $(12.50 \%)$ and in group E $(21.75 \%)$.

The antibiotic used as the previuos recipe by doctor $(50.42 \%)(\mathrm{P}<0.05)$, in group A $(68.89 \%)$, in group B (43.14\%), in group $\mathrm{C}(57 \%)$, in group D $(65.63 \%)$ and in group E $(32.97 \%)$ gathered on the same opinion.

I went to the doctor and used by consulted $(58.17 \%)(\mathrm{P}>$ $0.05)$, in group A $(73.33 \%)$, in group B $(58.82 \%)$, in group $\mathrm{C}(61 \%)$, in group $\mathrm{D}(64.06 \%)$ and in group $\mathrm{E}(49.45 \%)$ gathered on the same opinion 


\section{International Journal of Science and Research (IJSR) \\ ISSN (Online): 2319-7064 \\ Index Copernicus Value (2013): 6.14 | Impact Factor (2015): 6.391}

I asked the pharmacist and used by consulted $(36.29 \%)(\mathrm{P}<$ $0.05)$, in group A $(53.33 \%)$, in group B $(33.33 \%)$, in group $\mathrm{C}(34 \%)$, in group D $(17.19 \%)$ and in group $\mathrm{E}(49.45 \%)$ gathered on the same opinion.

3.4.11. How do you use an antibiotic when you last infection

The result of obtained for until ends the course for all groups $(15.79 \%)(\mathrm{P}>0.05)$, in group A $(29.67 \%)$, in group B $(13.73 \%)$, in group $\mathrm{C}(15 \%)$, in group $\mathrm{D}(6.25 \%)$ and in group $\mathrm{E}(20.88 \%)$ gathered on the same opinion.

According to the doctor's advice $(61.77 \%)(\mathrm{P}<0.05)$, in group A $(77.78 \%)$, in group B $(60.78 \%)$, in group $\mathrm{C}(66 \%)$, in group D $(76.56 \%)$ and in group E $(45.15 \%)$ gathered on the same opinion.

For until the symptoms disappear $(47.09 \%)(\mathrm{P}<0.05)$, in group A $(55.56 \%)$, in group B $(25.94 \%)$, in group C(42\%), in group D $(32.81 \%)$ and in group E $(60.44 \%)$ gathered on the same opinion.

3.4.12. Do you have an antibiotic in your home pharmacy?

The result of obtained if antibiotic used in a home pharmacy for all groups $(64.54 \%)(\mathrm{P}>0.05)$, in group $\mathrm{A}(80 \%)$, in group B $(64.71 \%)$, in group C $(68 \%)$, in group D $(51.56 \%)$ and in group $\mathrm{E}(69.23 \%)$ gathered on the same opinion opinion.

3.4.13. is the high temperature have any "fever" a strong motivation for the use of antibiotic:

The result of obtained for that he considers high temperature have any "fever" a strong motivation for the use of the antibiotic for all groups $(60.66 \%)(\mathrm{P}<0.05)$, in group $\mathrm{A}$ $(91.11 \%)$, in group B $(54.90 \%)$, in group C $(64 \%)$, in group D $(46.88 \%)$ and in group E $(61.54 \%)$ gathered on the same opinion.

3.4.14. do you expect that it is necessary to take antibiotics if the disease is caused by a virus such as cold:

The result obtaind as it was necessary to take antibiotics if the disease is caused by a virus such as cold for all groups $(55.95 \%)(\mathrm{P}>0.05)$, in group A $(80 \%)$, in group B $(45.10 \%)$, in group $\mathrm{C}(52 \%)$, in group D $(59.03 \%)$ and in group $\mathrm{E}(58.27 \%)$ gathered on the same opinion.

\subsubsection{Have you ever heard of before all the bacteria resistance to antibiotics? \\ The result of obtained regarding to hear before about bacterial resistance to the antibiotic for all groups was $(52.35 \%)(\mathrm{P}<0.05)$, in group $\mathrm{A}(55.56 \%)$, in group $\mathrm{B}$ $(54.90 \%)$, in group $\mathrm{C}(53 \%)$, in group D $(71.88 \%)$ and in group E (40.66\%) gathered on the same opinion.}

\section{Discussion}

In many areas of the world irrational use of antibiotic is a general problem. Also it has been an issue concerned all over the world and the outlooks in developing countries are more severe.In this study showed that there was a very limited knowledge about antibiotics used and misuse among university students in Hail.
It was seen that the use of antibiotics with medical prescriptions (60 out of 64) was more appropriate in pharmacy students than other students.

For the purpose to use antibiotic to reduce heat, overcome te pain, overcome weakness and fatigue was more appropriate in pharmacy and science students than other students as shown in table 4. During their last infection about (47.09\%) $(\mathrm{P}<0.05)$ of all groups used antibiotics until the symptoms disappeared or until the bottle had finished (15.79\%) $(\mathrm{P}>0.05)$.

It was concluded that knowledge and education did not always correlate with behaviour.

Efforts should be directed at educating people to change their behaviour and attitude about the rational use of antibiotics to decrease resistance rates.

As mentioned above the other type of inappropriate use of antibiotics was related with the dose and the period of the prescribed antibiotic.

For how long is use of antibiotic for all groups in total $(37.95 \%)(\mathrm{P}>0.05)$ of the students said that it is true to continue to use antibiotics until the symptoms improve.

We found that $(53.46 \%)(\mathrm{P}<0.05)$ f the students believed that antibiotics could be used to overcome the fever and $(31.58 \%)$ $(\mathrm{P}<0.05)$ believed that antibiotics used to overcome the weakness and fatigue.

Although we found in our study irrational use of antibiotics among university students in contrast to that we found that over $(79.50 \%)$ of students used antibiotics by medical prescription $(\mathrm{P}>0.05)$.

The prevalence of self medication of antibiotics in the present study was similar to that reported to the community of Abu Dhabi, Iranian and Jordanian students. This was in harmony with the previous studies of $(5,6,7)$.

However, our results indicate that there was poorer knowledge of students in Hail when compared with students from Turkey (8).

In addition to that, $(46.26 \%) \quad(\mathrm{P}<0.05)$ believed that antibiotics could be used for the treatment of common cold, it is maintained that many people do not understand the differences between bacteria and viruses and were believed that antibiotics were effective against both.

Although we found in our study irrational use of antibiotics among university students in contrast to that we found that over $(79.50 \%)$ of students used antibiotics by medical prescription $(\mathrm{P}>0.05)$.

The prevalence of self medication of antibiotics in the present study was similar to that reported to the community of (9), and (10) students.

Many factors may contribute to the high prevalence of selfmedication with antibiotics including the lack of time to visit 


\section{International Journal of Science and Research (IJSR) \\ ISSN (Online): 2319-7064}

Index Copernicus Value (2013): 6.14 | Impact Factor (2015): 6.391

a clinic due to study schedule. Moreover, $(15.79 \%)(\mathrm{P}>0.05)$ of students using antibiotics without completing the course of treatment and $(33.24 \%)(\mathrm{P}<0.05)$ begin used antibiotics by themselves when they were sick but most of them $(57.89 \%)(\mathrm{P}$ $<0.05)$ stopped taken it and go to the doctor when they thought the antibiotic is not effected. While (35.73\%) stopped taken it and go to another doctor and (35.73\%) (P < $0.05)$ had taken it in a specified period. About $47.09 \%$ ( $\mathrm{P}<$ $0.05)$ of the respondents used antibiotics until the symptoms disappeared during their last infection. This approximately compatible with (11).In the present study there were $(52.35 \%)$ ( $\mathrm{P}<0.05)$ of students heard about the bacteria resistance to antibiotics before. This in agreement with the previous study of (12).

Although there was a wide irrational use of antibiotics among university students in our study, there are some of them have high knowledge of antibiotics used leads to rational uses as $(57.89 \%)(\mathrm{P}<0.05)$, of respondents. In our study students believed that antibiotics used to overcome the pain which indicate irrational use.

About $(28.53 \%)(\mathrm{P}>0.05)$ started took antibiotic found at home to avoid loss of time, that mean they have awareness about rational use. In the present study result $(68.70 \%)(\mathrm{P}>$ $0.05)$ of students thought that the use of inappropriate antibiotic may had any dangerous. Also, (58.17\%) ( $\mathrm{P}<$ $0.05)$, went to the doctor and took antibiotic by consulted. $(64.45 \%)$ ( $\mathrm{P}>0.05)$, have an antibiotic in their home pharmacy. (55.96\%) $(\mathrm{P}>0.05)$, expect that it was necessary to take antibiotic if the disease is caused by a virus such as cold, although $(61.77 \%)(\mathrm{P}<0.05)$ of all groups agree that antibiotics should be started with doctors' prescription in our study we found the irrational use of antibiotic this may be related to that student not follow the dosage schedule or not complete the requested duration of the drug.

\section{Conclusion}

In the present study results showed that self-medication and the irrational use of antibiotics were common among university student in Hail. The rational use of ntibiotics may be favored by improving knowledge about these drugs. Such an idea should be made clear to the public, where many diseases would become very difficult to treat with the currently known antibiotics. The mass media could be used to educate every one, television, newspapers and leaflets could very useful and accessible for such purpose.It was obvious that level of education did not correlate with self medication.National education programs about the danger of irrational antibiotic use and restriction of antibiotic without prescription should be the priority.

\section{References}

[1] Asperheim MK, Favaro J, (2012). Introduction to pharmacology, twelfth edition, chapter7, page 49.

[2] Barden LS, Dowell SF, Schwartz B, et al. Current attitudes regarding use of antimicrobial agents: results from physician's and parents' focus group discussions. Clin Pediatr 1998; 37:665-71.

[3] Kunin CM, Liu YC. Excessive use of antibiotics in the community associated with delayed admission and masked diagnosis of infectious diseases. J Microbiol Immunol Infect 2002;35:141-6.

[4] KD Tripathi, (2013). Essentials of MEDICAL PHARMACOLOGY, $7^{\text {th }}$ edition, chapter5, page 69.

[5] Abasaeed, A., Jiri, V., Mohammed A., and Ales, K.(2009). Self-medication with antibiotics by the community of Abu Dhabi Emirate, United Arab Emirates, J infect Dev Ctries;3(7).491-497.Aug.

[6] Sarahroodi, S., Arzi, A., Sawalha, A.F.and ashtranezhad (2010). A., Antibiotic self-medication among Southern Iranian university students. Int.J. Pharmacol., 6 (1). 4852.

[7] Al-Azzam, S.I., Al-Husein, B.A., AlZubi, F., Masadeh, M.M., and Al-Horani, M.A.S (2007). Self-medication with antibiotics in Jordanian population. Int. J. Oсcup. Med. Environ. Health, 20(4). 373-380.

[8] Buke C, Hosgor-Limoncu M, Ermertcan S, Ciceklioglu M, Tuncel M, Köse T, et al. (2005). Irrational use of antibiotics among university students. Journal of infection. 51(2):135-139.

[9] Huang Y, Gu J, Zhang M, Ren Z, Yang W, Chen Y, et al. (2013). Knowledge, attitude and practice of antibiotics: a quesctionnaire study among 2500 Chinese students. BMC medical education. 13(1):16

[10] Sanya T, Titilayo O, Adisa R, Segun J. (2014). Use of antibiotics among non-medical students in a Nigerian university. African health Sciences. 13(4):1149-55.

[11] Cagri bulk, mine hosgor, safak ermertcan, et al. (2005). Irrational use of antibiotics among university students ;51, 135-139.

[12] Kumar Bishwajit Sutradhar, Anamika Saha, Naz Hasan, et al. (2014). Irrational Use of Antibiotics and Antibiotic Resistance in Southern Rural Bangladesh. Annual Research \& Review in Biology; 4(9).

\section{Author Profile}

Halima Mustafa Elagib received the B.Pharm. M.Pharm. and PhD degrees in Pharmacy from Khartuom University/Sudan in 1993, 2001 and 2008, respectively. I was working in Omdurman Islamic University faculty of pharmacy, Department of Pharmacology /Sudan until 2012.Now Iam working in University of Hail faculty of Medicine/ Saudi Arabia from 2012 until now. $4^{\text {th }}$ year, University of Hail faculty of Medicine/ Saudi Arabia

Raya Khaled Ali Al-Tamimi, $4^{\text {th }}$ year, University of Hail faculty of Medicine/ Saudi Arabia

Ghadh Fahad Solaiman Alolaiqi, $4^{\text {th }}$ year, University of Hail faculty of Medicine/ Saudi Arabia

Nouf Awwad Bakhet Algharbi, $4^{\text {th }}$ year, University of Hail faculty of Medicine/ Saudi Arabia

Bayan Abdulkarim Abdullah Alsamaan, $4^{\text {th }}$ year, University of Hail faculty of Medicine/ Saudi Arabia

Doha Nasser Alhumaidy Alsharedah, $4^{\text {th }}$ year, University of Hail faculty of Medicine/ Saudi Arabia

Nouf Mohammed Abdullah Almohaimel, $4^{\text {th }}$ year, University of Hail faculty of Medicine/ Saudi Arabia 